\title{
Understanding Indigenous Reconciliation Action Plans from a Corporate Social Responsibility Perspective
}

\author{
Dr Daniel Schepis, Senior Lecturer \\ The University of Western Australia \\ daniel.schepis@uwa.edu.au
}

To cite: Schepis, D. (2020). Understanding Indigenous Reconciliation Action Plans from a corporate social responsibility perspective. Resources Policy, 69, 101870.

\begin{abstract}
Many local and foreign companies operating in Australia are now establishing Reconciliation Action Plans (RAPs) to commit to and report on specific activities for engaging Indigenous stakeholders. While RAPs appear to align with existing approaches of sustainability reporting, these disclosure practices are yet to be empirically investigated within the broader context of CSR, or specifically the implications for stakeholder theory perspective. This paper examines RAP reporting practices over a thirteen year period, as well as how firms disclose reconciliation activities into their sustainability reporting and whether firms with RAPs disclose more 'reconciliation' activities than others. A content analysis is performed based on a sample of RAPs, sustainability reports and website data from companies operating in the Australian resources sector. Results indicate that firms do integrate reconciliation activities into their general sustainability reporting, however the quality of disclosure was in most cases low. The analysis also shows that on average, firms with RAPs do disclose reconciliation activities in greater detail than similar firms without. These findings provide a new empirical understanding embedded within theoretical perspectives of CSR, to support further integration of RAPs across industry and improve community impact.
\end{abstract}

Keywords: CSR; Sustainability Reporting; Extractive Industries; Indigenous Engagement 


\section{Introduction}

Research into corporate social responsibility (CSR) has identified continuous growth in the number of firms engaging in activities to meet stakeholder expectations of economic, social and environmental performance, along with a proliferation of collective initiatives and greater sophistication of reporting frameworks (Aguinis \& Glavas 2012; Sethi et al., 2016). Many firms are exploring new approaches to better engage key stakeholders and communicate their contributions and impacts in a more targeted and effective manner (Pérez 2015). This is particularly true for firms in the resources sector which face high levels of scrutiny and expectations to mitigate impacts and provide stakeholder benefits from commercial activities (Fuisz-Kehrbach, 2015; Ranängen \& Zobel, 2014). From a stakeholder theory perspective, CSR reporting is considered a legitimizing practice through which firms inform and convince stakeholders of their positive intentions and outcomes (Campopiano \& De Massis, 2015). Despite ongoing evolution, integrity issues continue to tarnish CSR practices, with opaque reports often lacking detail or not reflecting the firm's actual performance (Utting, 2005; Fonseca, 2010; Milne \& Gray, 2013). Indeed, given the strategic application of CSR, its format and standards vary greatly across industry and country contexts, limiting our theoretical interpretations (Chen \& Bouvain, 2009; Hahn \& Kühnen, 2013). To make sense of emerging CSR reporting practices we therefore require in-depth critical analysis which looks beyond surface level rhetoric (Ranängen \& Zobel, 2014).

The scope of CSR activities can target general social or environmental topics, or more specific stakeholder expectations (Aguinis \& Glavas, 2012). In line with the latter, this paper explores the use of Reconciliation Action Plans (RAPs) by resources sector firms, which contain a standardised framework of public commitments to undertake and report on internal and external activities that promote Indigenous reconciliation in Australia. Unlike legally mandated forms of Indigenous-corporate engagement such as Impact \& Benefit Agreements in Canada or Indigenous Land Use Agreements (ILUA) in Australia, RAPs are voluntary and therefore a distinct structure to examine (Craik et al., 2018). Beyond their voluntary nature, these plans have several properties akin to other CSR initiatives, as they follow a standardised framework which is endorsed and managed by an external agency, yet all commitments are determined by the firm (Raufflet et al., 2014). RAPs may however represent a more ethical and sustainable approach for businesses to engage Indigenous people in a meaningful way outside of legal structures and generic community engagement (Lertzman \& Vredenburg, 2005). This is particularly relevant to the resources sector given the significance of Indigenous stakeholders and longstanding tensions relating to corporate approaches to community relationships and operational impacts (Crawley \& Sinclair, 2003; Langton \& Mazel, 2008).

While this initiative commenced over a decade ago, alarmingly, we have no empirical research into stakeholder or company outcomes, nor do we understand how these specific activities fit into companies' broader CSR strategies. To better understand corporate approaches to RAPs, this study seeks to first articulate the content of RAPs within the context of CSR and then explore their integration into resources sector firms' sustainability disclosures. To account for many of the contextual variances influencing CSR reporting practices, the analytical frame is narrowed to a specific industry context, enabling comparison between firms which have adopted these plans and those that haven't. Using reporting as a way to identify corporate approaches, this study investigates the following research questions: (1) how can RAPs be understood from a CSR reporting perspective; (2) how do firms integrate reconciliation activities into their sustainability reporting? and (3) whether firms with RAPs disclose more detailed 'reconciliation' activities than others? By exploring these questions, this paper contributes a foundational understanding of RAPs, contextualized within the context of CSR 
and establishes future research direction for investigating this new form of Indigenous engagement in the resources sector.

The structure of the paper is as follows. First the RAP context is explained and contextualised within CSR, followed by an exploration of the role of disclosures and reporting initiative in CSR strategy. The contextual setting is then outlined, followed by the methodology based on a content analysis of sustainability disclosures within the Australian resources sector. Thereafter the results are presented, concluding with a discussion of findings and agenda for future research.

\section{Background to RAPs}

Within the Australian context, reconciliation quite broadly refers to the building of relationships, respect and trust between Aboriginal and Torres Strait Islander peoples and the wider Australian community (Reconciliation Australia, 2016). This agenda was formalised through the Federal Government's formation of the Council for Aboriginal Reconciliation in 1991, which later evolved into an independent, not-for-profit foundation, Reconciliation Australia (RA). In 2006, RA launched a unique RAP program with the slogan 'turning good intentions into actions, thereby establishing a platform for various organisations to engage and report on practical reconciliation activities (Lloyd, 2018). RAP documents have a standardised framework based on three pillars: Relationships, Respect and Opportunities, from which organisations develop and commit to specific actions which are officially endorsed by RA (See Table 1). Organisations that sign up to the initiative are required to report on their outcomes annually and also review their activities and targets after a set timeframe. In 2013, four tiers of RAPs were established (Reflect, Innovate, Stretch and Elevate), which organisations are expected to progress through, gradually becoming more comprehensive and building on past efforts (Lloyd, 2018).

Table 1. Description of Reconciliation Action Plan Pillars

\begin{tabular}{|c|c|c|c|}
\hline $\begin{array}{l}\text { RAP } \\
\text { Pillar }\end{array}$ & Description & Activities Included & $\begin{array}{c}\text { Example Actions } \\
\text { (Whitehaven Coal RAP } \\
\text { 2018-2020) }\end{array}$ \\
\hline 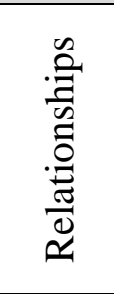 & $\begin{array}{l}\text { The development of } \\
\text { supportive } \\
\text { partnerships with } \\
\text { Aboriginal and Torres } \\
\text { Strait Islander } \\
\text { organisations. }\end{array}$ & $\begin{array}{l}\text { Establishing partnerships } \\
\text { Donations } \\
\text { National Reconciliation } \\
\text { Week Participation } \\
\text { Raising awareness of RAP } \\
\text { Pro bono services }\end{array}$ & $\begin{array}{l}\text { Provide opportunities for } \\
\text { employees to support and } \\
\text { celebrate National } \\
\text { Reconciliation Week } \\
(N R W)\end{array}$ \\
\hline 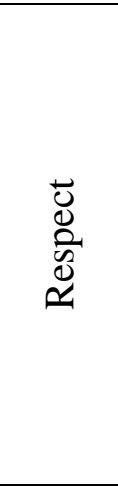 & $\begin{array}{l}\text { Facilitating cultural } \\
\text { learning within the } \\
\text { organisation and } \\
\text { adopting cultural } \\
\text { protocols to } \\
\text { acknowledge } \\
\text { Aboriginal and Torres } \\
\text { Strait Islander people. }\end{array}$ & $\begin{array}{l}\text { Cultural awareness training } \\
\text { for staff } \\
\text { Establish and promote } \\
\text { cultural protocols } \\
\text { Celebrate significant } \\
\text { Aboriginal and Torres Strait } \\
\text { Islander events } \\
\text { Include Aboriginal and } \\
\text { Torres Strait Islander } \\
\text { community in events } \\
\end{array}$ & $\begin{array}{l}\text { Deliver Cultural } \\
\text { Awareness Training to } \\
\text { increase knowledge and } \\
\text { understanding of } \\
\text { Aboriginal and Torres } \\
\text { Strait Islander cultures, } \\
\text { histories and } \\
\text { achievements }\end{array}$ \\
\hline
\end{tabular}




\begin{tabular}{|c|c|c|c|}
\hline 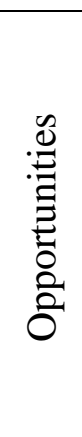 & $\begin{array}{l}\text { Contributing to } \\
\text { Aboriginal and Torres } \\
\text { Strait Islander } \\
\text { education, } \\
\text { employment and } \\
\text { business development. }\end{array}$ & $\begin{array}{l}\text { Aboriginal and Torres Strait } \\
\text { Islander employment and } \\
\text { retention } \\
\text { Employment training and } \\
\text { professional development } \\
\text { Procurement from } \\
\text { Aboriginal and Torres Strait } \\
\text { Islander businesses } \\
\text { Provision of scholarships }\end{array}$ & $\begin{array}{l}\text { Expand pathways to } \\
\text { employment for } \\
\text { Aboriginal and Torres } \\
\text { Strait Islander peoples }\end{array}$ \\
\hline
\end{tabular}

An increasing number of private, public and not-for-profit sector organisations are establishing RAPs, with over 1000 created since the concept was launched. Over 1.9 million people currently work or study in an organisation with a RAP and members of these organisations report greater contact, less prejudice and more trust towards Aboriginal and Torres Strait Islander people than the general population (Reconciliation Australia, 2018). Similarly, at the organisational level, positive impacts of RAPs are seen to be higher Indigenous employment, greater spending on contracts with Indigenous suppliers and more support for pro bono services, scholarships and traineeships; however no comparative analysis with non-RAP firms exists (ibid). Of the limited research exampling RAP impacts on organisational behaviour, one review found mixed results at the workplace level, with a half of all employees unaware their employer has a RAP; however there are positive outcomes among those participating in RAP activities (Polity, 2016). Fordham et al. (2018) found that within their Australian mining industry sample, RAPs are more prevalent in medium to large scale companies with global operations and were perceived to help guide and justify CSR strategy and programs.

Despite the standardised framework, analysing RAP approaches and performance is difficult, primarily due to the types of initiatives and targets varying greatly by organisational type. It is clear that Indigenous engagement is on the agenda of many prominent Australian companies, as evidenced that 52 of the Business Council of Australia's members report having a published RAP or in the development process, while $90 \%$ have Indigenous engagement activities (BCA, 2016). However, we cannot assume diverse firms have common motivations for voluntarily committing resources to reconciliation endeavours (Heard et al., 2017). Additional layers of complexity apply in certain industries, such as the resources sector, whereby these activities are often tied to land access agreements (O'Faircheallaigh, 2013). The RAP program may therefore align with stakeholder management perspectives of CSR, given the tendency for firms to focus efforts on groups with most power to influence operations (Fordham et al., 2017). Indeed, engaging in structured CSR programs to benefit local communities is considered key to demonstrating social licence to operate in the mining industry (Bice, 2014).

\subsection{Understanding RAPs from a CSR Perspective}

At present, there has been little theoretical investigation into corporate involvement in reconciliation activities and as such the role of RAPs in CSR is largely unknown. However, it is clear that Indigenous people represent important stakeholders for firms operating in Australia, a status is becoming increasingly embedded in corporate strategy (Crawley \& Sinclair, 2003; Langton \& Mazel 2008; Coronado \& Fallon, 2011; O'Faircheallaigh, 2015). The private sector is increasingly expected to play an active role in Indigenous education, health and employment outcomes, traditionally considered a government domain (Langton 2015; Fordham et al. 2018). Within such a socio-political environment it is imperative that firms update their Indigenous engagement policies and practices to reflect the expectations of 
relevant stakeholders and the general public (Trebeck, 2008; Humphries, 2014). This perspective therefore closely aligns with conceptualisations of CSR as "the pursuit of socioeconomic goals through the elaboration of social norms in prescribed business roles", (Johnson 1971, p. 51).

Certain elements of RAPs focusing on relationship building, consultation and cultural awareness are common stakeholder engagement practices found in different contexts (Hilson, 2012; Prno \& Slocombe, 2012). These activities represent positive progress from Crawley and Sinclair's (2003) study of Australian mining companies, which did not identify any that had reached that level of maturity in their relationships with Indigenous stakeholders. More recently, Fordham et al. (2018) identify a prevalence of Indigenous-specific programs within mining companies CSR practices, targeting at varied forms of capital development; suggesting a maturation of corporate approaches. This may also be reflected in the inclusion of internallyorientated RAP activities aimed at establishing patterns for cross-cultural literacy and substantive dialogue, which in turn can promote sustainable development (Lertzman \& Vredenburg, 2005). Such activities may improve firms' capacity to develop mutually beneficial relationships with Indigenous communities, thereby supporting positive CSR outcomes more broadly (Langton, 2015). Other RAP activities such as the promotion of Indigenous employment, training or contracting opportunities, align with broad affirmative action practices found elsewhere in the world, however those included in RAPs are entirely voluntary and do not cover contractual commitments made in ILUAs or other legislated requirements (Daly et al., 2013).

There are several possible explanations for companies' participation in the RAP program over less onerous or more flexible avenues to addressing their social responsibilities, such as the ability to abandon in unfavourable economic conditions and less stringent governance (O'Faircheallaigh, 2015). Humphreys (2014) suggests, strategic partnerships with non-profit organisations representing a cause, provide companies legitimacy in that domain and align them with the norms and expectations of that group. Moreover, the RAP format can be perceived as a form of voluntary CSR disclosure, which in itself represents an attempt at legitimation (Van Der Laan, 2009). Based on the public nature of RAP reporting, parallels with other sustainability reporting frameworks such as GRI are evident, as they both offer recognition of compliance with set standards (Fuisz-Kehrbach, 2015). The emergence of new forms of community engagement discourses and practices such as RAPs, necessitates critical analysis to examine and understand these activities (Mayes et al., 2014).

\subsection{Exploring CSR Strategy through Disclosures}

In analysing CSR strategies, researchers often rely on company-produced reports and other publications to identify relevant activities and performance. These pragmatic approaches acknowledge the methodological limitations relating to reliability and transparency issues, thereby not assuming accuracy and instead valuing rhetorical insights into corporate strategy (Fuisz-Kehrbach, 2015). It has also been argued that the development of CSR practices is inextricably linked with the emergence of non-financial corporate reporting and other forms of communication, all seeking to satisfy increasing public scrutiny and stakeholder expectations (Lozano \& Huisingh, 2011; Milne \& Gray, 2013; Russo-Spena et al., 2015). CSR disclosures are among companies' most visible and widely published documents and represent effective means of communicating with key external stakeholders (Jenkins \& Yakovleva, 2006; Hetze, 2016). Firms are not only disclosing more information relating to their social and environmental performance, but these disclosures are increasingly being released in dedicated stand-alone reports in regularity akin to traditional financial reporting practices (Hahn \& 
Kühnen, 2013). Yet, as Milne and Gray (2013) highlight, the low quality and lack of progress of sustainable development reporting is often criticised.

In recognising the strategic value of CSR, it is acknowledged that disclosing firms present favourable corporate images that enable them to achieve their objectives (Van Der Laan, 2009; Boiral 2013). Moreover, the quantity and quality of CSR reporting is greatly influenced by firm size, which may further loosen the relationship between disclosures and actual practices (Lee, 2017; Nijhof et al. 2008). While the insights available from these disclosures are limited and often skewed, they are considered to be representative of corporate attitudes to sustainability and offer good bases for comparison between companies and development over time (FuiszKehrbach 2015). The level of detail disclosed on different sustainability topics can be considered indicative of their attention to the issue or stakeholder group (Boiral 2013). Insight can be gained by analysing the presence and absence of certain disclosures, with materiality processes and contexts illuminating corporate CSR strategies (Unerman \& Zappettini 2014; Russo-Spena, Tregua \& De Chiara 2015).

\subsection{Voluntary Reporting Initiatives}

In examining RAPs as a strategic practice, we therefore use reporting as a lens to understand corporate approaches in the absence of reliable data of the actual activities they describe. RAPs can be characterised as a voluntary reporting framework, aligning with a growing trend of similar initiatives seeking to address issues of quality and consistency in sustainability reporting. These initiatives are typically facilitated by external bodies such as the Global Reporting Initiative (GRI) or industry and country specific variations that set standards of the type and detail of information to be disclosed (Raufflet et al., 2014). Partnerships or endorsement from external bodies can strengthen firms' CSR efforts through their expertise and relationships with stakeholders, while also providing normative legitimacy Conley \& Williams 2005; Nijhof et al., 2008). CSR frameworks have been considered to serve as regulatory scripts, through which companies are able to show alignment with institutional expectations (Ranängen \& Zobel, 2014). While standardisation initiatives seek to harmonize reporting styles and content, it is also suggested that they offer corporations the ability to "pick and choose' criteria to follow based on convenience or preference, which contributes to ongoing differences in reporting quality (Chen \& Bouvain 2009; Raufflet et al., 2014).

Despite advances in the number of firms engaging in CSR and in the amount of disclosures, companies are still scrutinised regarding their level of commitment and the actual outcomes and beneficiaries of these activities (Hilson 2012; Milne \& Gray 2013). From a mining perspective, Bice (2017) points to the difficulties in identifying whether the diffusion of disclosures are primarily driven by mimetic (e.g. reporting by a critical mass of firms in the industry) or coercive (e.g. demands of institutional membership). Michelon et al. (2015) identify many emergent practices are often largely symbolic and do not necessarily improve reporting quality. Similarly, participation in voluntary initiatives does not automatically suggest greater external accountability and some companies may be concerned with the appearance of accountability to fulfil strategic aims (Hess 2008). Increasing transparency is not always in firms' best interests and instead, disclosing unmeasurable and unspecific information reinforces managerial control over firm image (Boiral \& Henri, 2017). This aligns with criticisms of agreement making practices within the Australian mining industry, whereby confidentiality conditions inhibits evaluation and monitoring of terms, as well as the diffusion of best practice across the industry (Langton, 2015).

\section{The Case of CSR in the Australian Resources Sector}


The resources sector represents an appropriate case to analyse RAP use given the widespread adoption of CSR activities, proliferation of disclosure standards and frameworks and history of engagement with Indigenous stakeholders in Australia (Fuisz-Kehrbach 2015; Ranängen \& Zobel, 2014). Many mining, oil and gas companies were among the earliest adopters of RAPs and this remains one of the most represented industries in RA's database (BCA, 2014; Heard et al. 2017). Engagement with Indigenous groups is common practice for resources sector firms operating in Australia, with many entering into agreements with local Traditional Owner groups to enhance the security of their capital investments (Crawley \& Sinclair, 2003). A key driver of this practice was the introduction of Native Title legislation in 1993, granting Traditional Owners certain land rights and a degree of influence over mining projects through a right to negotiate over mining leases (Crawley \& Sinclair 2003; Parsons 2008). Although limited, these rights have been exercised to significantly influence the development of resource projects such as the Jabiluka uranium mine and the Browse Basin LNG project (O'Faircheallaigh, 2013). Outside legal requirements, voluntary CSR activities remain important practices for companies to manage their relationships with Indigenous groups (O'Faircheallaigh, 2015). These activities have however contributed to positive economic impacts for Indigenous communities engaging with resources sector firms (Langton 2015).

Across many country contexts, resources sector firms are often regarded as leading proponents of CSR reporting and have been shown to disclose greater levels of social and environmental information than firms in other industries (Ranängen \& Zobel, 2014; Hilson 2012; Bice 2014). Resources sector firms were previously viewed as laggards or resistant to addressing environmental or social issues (Sethi et al. 2016); yet are now considered early adopters and innovators in approaches to CSR (Bice 2014). Industry level sustainability initiatives are gaining prominence, as evidenced by voluntary reporting guidelines set by the International Council on Metals and Mining (ICMM) and International Petroleum Industry Environmental Conservation Association (IPIECA), which also incorporate policies relating to Indigenous rights (Haalboom 2012). Despite this, CSR disclosures in the resources sector have been criticized as emphasising altruistic/philanthropic activities, particularly self-laudatory in nature, as opposed to tying sustainability to corporate strategy (Fuisz-Kehrbach 2015). Further work is required to determine how new reporting initiatives support governance arrangements and the implementation of CSR activities (Hilson 2012; Prno \& Slocombe 2012).

\subsection{Research Approach}

Given the nascent stage of the RAP initiative and lack of research into their application and outcomes in private sector contexts, corporate practices must not be taken only at face value without considering implications for Indigenous stakeholders. It is unclear whether RAPs align with broader CSR strategies or how this specific reporting framework is integrated into existing sustainability disclosures. This exploratory study therefore seeks to shed light on this phenomenon by investigating the content of RAPs produced in a specific industry, as well as evaluating the manner in which they are integrated in general CSR reporting platforms. In order to explore the relative impact of RAPs on corporate involvement in reconciliation, the analysis is extended to compare disclosures between firms with RAPs and those without.

\section{Methodology}

This study applies a content analysis approach to explore CSR disclosures of extractive companies operating in Australia. Content analysis has long been considered the most common research method to investigating corporate sustainability disclosure practices (Fifka 2013) and has been regularly applied to extractive industry contexts (Bice 2014; Raufflet, Barin Cruz \& Bres 2014; Boiral \& Henri 2017). While CSR disclosures are strategic tools that do not 
necessarily equate with actual activities, they can serve as useful proxies to evaluate corporate priorities and sometimes comparative benchmarks (Fuisz-Kehrbach 2015; Beck, Frost \& Jones 2018). This approach is appropriate for conducting transparent comparisons across companies and analysing reporting styles and quality based on a framework of common components (Fonseca 2010; Michelon et al. 2015). The focus on a single industry enables a clearer analysis of company disclosures by limiting the variance in operating environments (Russo-Spena, Tregua \& De Chiara 2015). Given the small sample of resources sector firms with RAPs, content analysis provides an opportunity to analyse data from all firms and incorporate different reporting formats. To account for limitations within reporting mechanisms, three disclosure sources are taken for each company, thereby presenting a more comprehensive picture of corporate strategy.

To compare across firms a framework was developed to include components central to the reconciliation program and assess the level of detail in which they are described (Hahn \& Kühnen 2013). Reconciliation components were determined based on the three pillars represented in the RAP framework (Relationships, Respect and Opportunities), with applicable activities defined based on RA's RAP reporting guide and Reconciliation Barometer. In line with the measures used by RA five components were identified: Partnerships with Aboriginal and Torres Strait Islander organisations, including pro bono services offered (Relationships); Cultural Learning such as cultural awareness training and ceremonies (Respect); Employment of Aboriginal and Torres Strait Islander workers (Opportunities); Business activities including number and dollar value of contracts with Aboriginal and Torres Strait Islander companies (Opportunities); and Education support including contributions to Aboriginal and Torres Strait Islander scholarships and training initiatives (Opportunities). In aligning with stakeholder perspectives of CSR, these activities may be targeted towards specific Traditional Owner groups, geographically communities or Indigenous people more broadly (Aguinis 2011; Campopiano \& De Massis, 2015).

Figure 1. Analytical Framework

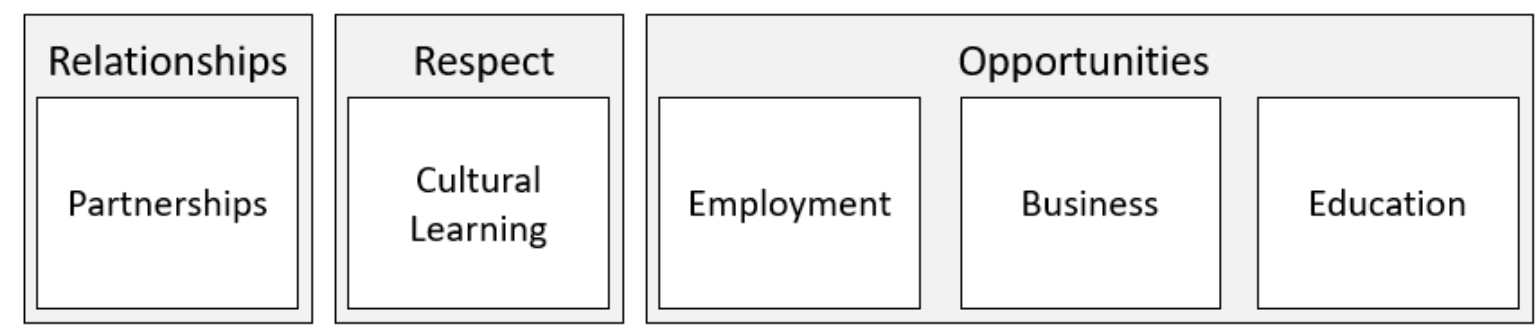

To assess the level of detail disclosed in relation to these components, the content scale from the consolidated narrative interrogation (CONI) methodology (Table 2) was adopted as an evaluative tool of reporting quality (Beck et al., 2010). This scale is used to evaluate content in terms of information content and character, assessing not just the level of information but also the depth and detail included (Beck et al., 2010). It also serves as an appropriate comparative measure, being originally used to contrast British and German firms. This scale captures a broad range of disclosure practices, from Type 1 which merely address an issue in minimal detail at a general level, to Type 5 which represents a comprehensive disclosure including qualitative narrative, numerical information and is contextualised through comparison to previous measures, targets or trends (Beck et al., 2010). For the purposes of this study, disclosures were assigned a single score for each component, based on the highest level of disclosure type identified. This was due to the specific research approach and nature of the data sample which made longitudinal and volumetric measurement inappropriate. 
Table 2. Content Scale

\begin{tabular}{|l|l|}
\hline Type & Disclosure Definition \\
\hline 0 & does not address issue \\
\hline 1 & addresses issue related to category definition; pure narrative \\
\hline 2 & addresses issue related to category and provides details; pure narrative \\
\hline 3 & addresses issue related to category in numerical way purely quantitative \\
\hline 4 & $\begin{array}{l}\text { addresses issue related to category in numerical way, including qualitative } \\
\text { explanations; } \text { narrative and quantitative }\end{array}$ \\
\hline 5 & $\begin{array}{l}\text { any numerical disclosure to the category including qualitative statements } \\
\text { demonstrating year comparisons; } \text { narrative, quantitative and comparable }\end{array}$ \\
\hline
\end{tabular}

Disclosures were thoroughly read in their entirety, in conjunction with a systematic keyword search process, with each mention to reconciliation activities coded and assigned to one of the five related components. Each coded text passage was then evaluated from 1 to 5 based on the type of disclosure it matched and no information pertained to a component, a 0 was recorded. To limit subjective bias, a second independent researcher was then asked to evaluate each passage using the same criteria to ensure the reliability of the coding process; with no notable differences identified. Companies were given a score for each component, based on the level of disclosure identified.

\subsection{Sample}

A purposeful sample was identified based on mining, oil and gas extraction firms operating in Australia that had at some point officially registered a RAP on the RA database (Table 3a). A total of fourteen companies fit that criteria and therefore to perform a comparative analysis, a further fourteen companies that did not have RAPs were also identified. The non-RAP sample was similarly selected based on mining, oil and gas firms that had current extraction operations in Australia and were of a sufficient size and public profile to release sustainability reports (Table 3b). The total sample consisted of a mixture of Australian (16) and overseas (12) headquartered firms with mining (13), oil and gas (11) and diversified (4) operations. Of the RAP sample, 10 had active RAPs, while 4 had inactive RAPs no longer listed in the RA database, including QGC which is since merged with Shell and Xstrata which is now part of Glencore.

Table 3a. Sample of Companies with Reconciliation Action Plans

\begin{tabular}{|l|c|c|c|c|c|c|}
\hline Company & $\begin{array}{c}\text { Total } \\
\text { Assets }\end{array}$ & Headquarters & Industry & $\begin{array}{c}\text { Report } \\
\text { Focus }\end{array}$ & $\begin{array}{c}\text { Report } \\
\text { Year }\end{array}$ & $\begin{array}{c}\text { Latest } \\
\text { RAP }\end{array}$ \\
\hline Anglo American & $\$ 76 \mathrm{~b}$ & UK & Diversified & Global & 2018 & $2014-15$ \\
\hline Arrow & $\mathrm{n} / \mathrm{a}$ & Australia & Oil \& Gas & - & - & $2015-16$ \\
\hline BHP Billiton & $\$ 147 \mathrm{~b}$ & Australia/UK & Diversified & Global & 2019 & $2017-20$ \\
\hline BP Australia & $\$ 411.1 \mathrm{~b}$ & UK & Oil \& Gas & Global & 2018 & $2018-20$ \\
\hline Chevron & $\$ 369.9 \mathrm{~b}$ & USA & Oil \& Gas & Global & 2018 & $2019-21$ \\
\hline Glencore $($ Xstrata) & $\$ 187.5 \mathrm{~b}$ & Switzerland & Diversified & Global & 2018 & $2014-16$ \\
\hline INPEX & $\$ 63.5 \mathrm{~b}$ & Japan & Oil \& Gas & Global & 2019 & $2019-22$ \\
\hline Newmont & $\$ 30.2 \mathrm{~b}$ & USA & Mining & Global & 2018 & $2018-20$ \\
\hline Origin & $\$ 25.7 \mathrm{~b}$ & Australia & Oil \& Gas & Global & 2019 & $2019-22$ \\
\hline Shell (incl. QGC) & $\$ 581.5 \mathrm{~b}$ & Netherlands & Oil \& Gas & Global & 2018 & $2013-15$ \\
\hline Rio Tinto & $\$ 132.5 \mathrm{~b}$ & UK & Diversified & Global & 2018 & $2016-19$ \\
\hline South 32 & $\$ 21.4 \mathrm{~b}$ & Australia & Mining & Global & 2019 & $2018-19$ \\
\hline Whitehaven Coal & $\$ 4.8 \mathrm{~b}$ & Australia & Mining & Aus & 2019 & $2017-20$ \\
\hline Woodside & $\$ 39.5 \mathrm{~b}$ & Australia & Oil \& Gas & Global & 2018 & $2017-20$ \\
\hline
\end{tabular}


Table 3b. Sample of Companies without Reconciliation Action Plans

\begin{tabular}{|l|c|c|c|c|c|}
\hline Company & $\begin{array}{c}\text { Total } \\
\text { Assets }\end{array}$ & Headquarters & Industry & $\begin{array}{c}\text { Report } \\
\text { Focus }\end{array}$ & $\begin{array}{c}\text { Report } \\
\text { Year }\end{array}$ \\
\hline Alcoa & $\$ 23.2 \mathrm{~b}$ & USA & Mining & Global & 2018 \\
\hline Anglogold Ashanti & $\$ 9.7 \mathrm{~b}$ & South Africa & Mining & Global & 2018 \\
\hline Beach Energy & $\$ 2.5 \mathrm{~b}$ & Australia & Oil \& Gas & Aus & 2019 \\
\hline ConocoPhillips & $\$ 101.7 \mathrm{~b}$ & USA & Oil \& Gas & Global & 2018 \\
\hline Evolution Mining & $\$ 3.1 \mathrm{~b}$ & Australia & Mining & Aus & 2019 \\
\hline FMG & $\$ 28.7 \mathrm{~b}$ & Australia & Mining & Aus & 2019 \\
\hline Iluka & $\$ 2.2 \mathrm{~b}$ & Australia & Mining & Global & 2018 \\
\hline New Hope & $\$ 2.9 \mathrm{~b}$ & Australia & Mining & Aus & 2019 \\
\hline Newcrest & $\$ 17.2 \mathrm{~b}$ & Australia & Mining & Global & 2019 \\
\hline Oz Minerals & $\$ 3.4 \mathrm{~b}$ & Australia & Mining & Global & 2018 \\
\hline Peabody & $\$ 10.8 \mathrm{~b}$ & USA & Mining & Global & 2018 \\
\hline Santos & $\$ 25 \mathrm{~b}$ & Australia & Oil \& Gas & Aus* & 2018 \\
\hline Senex & $\$ 427 \mathrm{~m}$ & Australia & Oil \& Gas & Aus & 2018 \\
\hline Yancoal & $\$ 12.4 \mathrm{~b}$ & Australia & Mining & Aus & 2018 \\
\hline
\end{tabular}

Two forms of disclosures analysed were analysed from each company: the latest sustainability report available and sustainability information found on the company's website. Three of the companies did not have current sustainability reports, in which case a Sustainability Performance Dataset was analysed for Santos, an Annual Report was analysed for Senex and only the website data analysed for Arrow Energy. Of the reports analysed 19 had a global focus, covering their operations in all countries, while 8 focused specifically on their Australian operations. Given globally focused reports had limited space to address reconciliation activities within the specific Australian context, an additional analysis was performed on website data which often had dedicated sites or subsections for addressing sustainability of their Australian operations. Analysing multiple sources provides a more complete understanding of corporate disclosure activity (Lee, 2017). All sites were accessed in January 2020.

\section{Results}

First, a case study of RAP development in the Australian resources sector to date is presented, applying content analysis to highlight identifiable trends. Second, a comparative analysis of disclosure quality is presented, examining disclosure of relevant RAP activities in other CSR reporting platforms, including among firms without RAPs.

\subsection{Exploration of RAPs in Resources Sector}

Since the initiative was first launched, a total of 31 RAPs have been released by 15 firms operating in the Australian Resources Sector. As the timeline in Figure 2 outlines, the take up of RAPs has increased during this period, however there are also four firms that have not continued to release updated plans. Curiously, Arrow Energy and Shell both refer to active RAPs on their websites, however they have no currently recognised RAP listed in RA's database. Among other notable trends is the gradual extension and specificity of time periods covered, adoption of RAP tiers to indicate progress and an increase in presentation standard, for example BHP Billiton's early RAPs only included text and scorecards, while all current RAPs also include commissioned Indigenous art, images and case studies. These trends suggest an overall increase in the professionalism and standardisation of RAPs, which may also be interpreted as greater corporate interest in their use as CSR communications.

\section{Figure 2. Timeline of Reconciliation Action Plans in the Resources Industry}




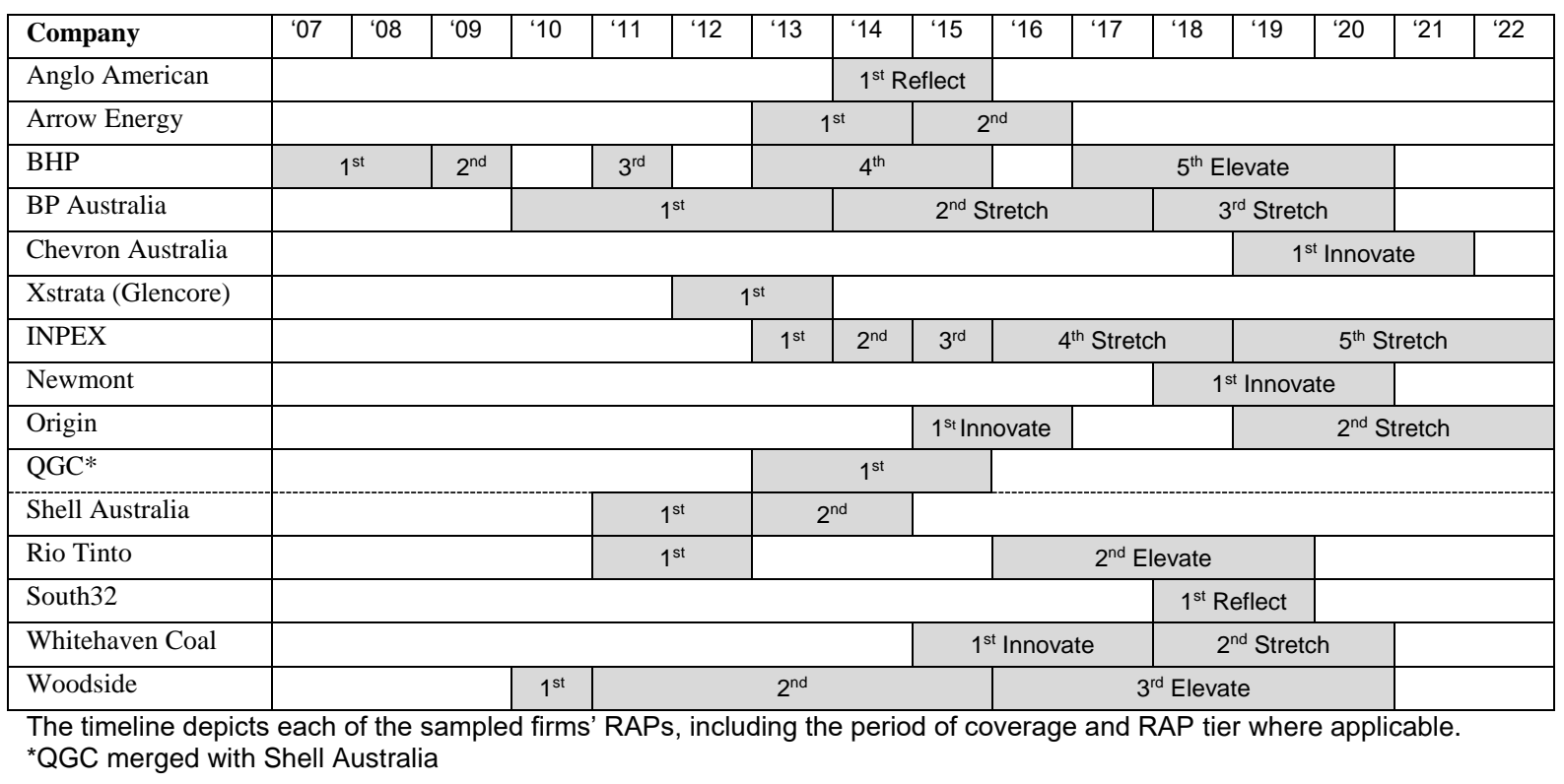

While RAPs follow a specified framework, the analysis identified a diversity of presentation styles and level of detail between companies, largely corresponding to the number of RAPs produced, sometimes described as the firm's 'Reconciliation Journey'. Considering a reporting perspective, Elevate RAPs can be seen to be the most details, providing detailed narrative, quantifiable figures to support commitments and transparent reporting of progress. As an example, the Woodside 2016-2020 RAP states: Together with our vendors, Woodside awarded 74 new contracts to Indigenous businesses in 2018. These contracts contributed to the $70 \%$ increase in total contracts awarded since 2016. A major contract was awarded to the Indigenous JV NWA, providing future opportunities to traditional owners and other local businesses (see Opportunities case study). Even between RAPs at the same level, companies have flexibility in reporting style which makes direct comparison difficult. For example BHP's Elevate RAP groups commitments under unique headings such as 'Economic Empowerment' and 'Social and Cultural Support', while Woodside's Elevate RAP utilises a unique 12 point 'Indicator of Success' template.

In relation to the specific commitments contained in the plan, notable variation is identified in scale of activities, resources contributed and level of development. For example many initial Reflect or Innovate RAPs refer broadly to the firm's intentions, planning processes or future activities not yet defined. For example, 'Anglo American will develop a business case for Aboriginal and Torres Strait Islander supplier diversity and research how Anglo American can develop and scope an Aboriginal and Torres Strait Islander program' or Chevron's commitment to 'Implement strategies to engage our staff in reconciliation'. This aligns with the RAP process of building firm understanding and capabilities over time, such as the Reflect stage which is intended for scoping; however, these do not present any tangible items to measure or track progress. Similarly some companies seek to incorporate existing activities into the RAP, without reporting clear outcomes or targets, for example South32 include 'Continue the Cannington Indigenous Traineeship program' and Chevron 'Continue to grow the number of Aboriginal businesses with which Chevron Australia conducts commercial transactions, directly and indirectly through our contractors and suppliers'. This can be contrasted by more mature RAPs which state clear targets, provide a timeline for achievement and identify responsible managers, thereby allowing for greater external accountability. 
It is unclear how other forms of stakeholder engagement such as ILUAs are accounted for within resource companies' RAPs, given they are aggregated to a national level without referring to specific agreements made with individual TO groups. While opaque, it does suggest RAPs are part of broader stakeholder management strategies, as suggested by references made to Native Title payments or consultation for new projects. Beyond the stated commitments, RAPs contain a number of insights related to corporate disclosure approaches. It is understood that endorsed RAPs require regular progress reports submitted to RA, however firms are not required to make them public. Within the sample analysed, some RAPs report outcomes from the previous version, others state lessons learned to suggest improvements and some firms make reference to separate progress reporting schedules. Such flexibility in disclosure suggests that RAPs, like other forms of CSR reporting cannot be taken as accurate descriptions of firm activities and performance.

\subsection{Broader Reporting of RAP Activities}

The second stage of the analysis involves an examination of how firms integrate RAP related activities across the other main reporting mechanisms, sustainability reports and websites. Table 4 presents average disclosure quality scores for the five reconciliation components (outlined in Figure 1), across the reports and websites of companies with and without RAPs. The examined disclosures did not directly reference RAPs but rather specific Indigenous engagement activities within the Australian context. A detailed breakdown for each component is included in Appendix A1-4.

Table 4. Averages of Disclosure Quality across all Components

\begin{tabular}{|l|c|c|l|c|c|}
\hline $\begin{array}{l}\text { RAP } \\
\text { Sample }\end{array}$ & $\begin{array}{c}\text { Report } \\
\text { Average }\end{array}$ & $\begin{array}{c}\text { Website } \\
\text { Average }\end{array}$ & $\begin{array}{l}\text { Non-RAP } \\
\text { Sample }\end{array}$ & $\begin{array}{c}\text { Report } \\
\text { Average }\end{array}$ & $\begin{array}{c}\text { Website } \\
\text { Average }\end{array}$ \\
\hline Anglo American & 0.2 & 1 & Alcoa & 0.2 & 0.4 \\
\hline Arrow Energy & - & 2 & Anglogold Ashanti & 0.4 & 0 \\
\hline BHP & 3 & 3 & Beach Energy & 0.6 & 0.4 \\
\hline BP & 1.2 & 1.6 & ConocoPhillips & 2 & 2.4 \\
\hline Chevron & 1 & 2.4 & Evolution & 1.8 & 1.8 \\
\hline Glencore & 1.4 & 1.8 & FMG & 3.8 & 3 \\
\hline INPEX & 3.2 & 2.8 & Iluka & 2 & 1.6 \\
\hline Newmont & 3 & 1.8 & New Hope & 0.4 & 0.2 \\
\hline Origin & 3 & 2 & Newcrest & 2.2 & 1.2 \\
\hline Rio Tinto & 2.4 & 2.4 & Oz Minerals & 1.4 & 2.2 \\
\hline Shell & 0.8 & 1.6 & Peabody & 0.8 & 0.2 \\
\hline South 32 & 1.2 & 2 & Santos & 0.4 & 2.4 \\
\hline Whitehaven Coal & 4 & 2.8 & Senex & 1.5 & 0.6 \\
\hline Woodside & 4.4 & 3 & Yancoal & 1.8 & 1.2 \\
\hline Average & $\mathbf{2 . 2}$ & $\mathbf{2 . 2}$ & Average & $\mathbf{1 . 4}$ & $\mathbf{1 . 3}$ \\
\hline
\end{tabular}

Averaged disclosure quality scores (0-5) for sustainability report and website content

Direct comparison between the two samples, indicates that for both sustainability reports and websites, firms with RAPs disclose information at a higher level of detail on average. With reference to the content analysis scale used, these firms were more likely to combine narrative with qualitative explanations, quantified data and yearly comparisons. As further basis for comparison, firms in the RAP sample included a total of 34, higher quality type 4 and 5 disclosures, while firms in the non-RAP sample only included 16. The inverse comparison shows that 24 instances of no references to activities (type 0) among firms in the RAP sample and 51 for firms in the non-RAP sample. Overall, little difference is noted between disclosures 
in reports or on websites, however at the firm level it is evident that some firms include more information in one format or the other. For larger firms such as Chevron and Shell, this may be due to their global scope and relative significance of their Australian operations which limited space available to detail these activities in reports, however, both had Australian specific websites. In contrast, smaller Australian firms such as Whitehaven and Newcrest, included more detail in reports and maintained relatively simpler websites with less content.

The company with the highest overall reporting quality average, Woodside, included descriptions of activities in a similar level of detail as in their RAP. For example, employment performance is quantified with yearly comparison and accompanied with contextual explanation: 'In 2018, we directly employed 130 Indigenous employees (3.7\% of the total workforce), compared to 117 in 2017 (3.3\% of total workforce). Voluntary Indigenous turnover remained steady at 2.4\%. Much of this positive growth in, and retention of, our Indigenous workforce has been driven through our sustainable pathways programs, strong graduate intake and ongoing engagement. In 2018, we had 31 Karratha-based Indigenous apprentices and trainees, 12 Indigenous vacation students undergoing tertiary study and work placement and 8 Indigenous candidates on the graduate development program. To support community-based careers and future employment opportunities within Woodside, we awarded 34 Indigenous scholarships, up from 21 in 2017'. The company's website in contrast is less direct, however includes an 'Indigenous Peoples' subsection within Sustainability containing news articles, video and policy documents relating to specific activities and events.

Most of the highest quality disclosures (BHP, INPEX, Whitehaven and Woodside), can be described as stemming from companies with greater RAP experience, as indicated by number and current level. These companies are also characterised as having significant Australian presences within their portfolio and therefore may dedicate more resources and attention to addressing Indigenous stakeholders. In contrast to this, FMG has never published a RAP, yet still includes a high level of detail on their Indigenous engagement activities across their sustainability report and website. As the following example shows, the disclosure detail of certain activities is similar to that contained in RAPs: 'Fortescue is also committed to spending a portion of its procurement budget with Aboriginal businesses. In FY19, Fortescue spent approximately A $\$ 236$ million with 54 Aboriginal businesses, representing 5.5 per cent of the Company's total contestable procurement spend with more than 90 per cent of the spend awarded to businesses owned by Native Title groups and their members'. FMG maintains its own 'Billion Opportunities' Indigenous engagement strategy, which focuses heavily on job creation and business contracting, is interlinked with the firm's Native Title and land access activities.

The overall standard of disclosure quality across the sample is quite low, compared to the level of detail included in RAPs, highlighting the distinction between specific and generic reporting mechanisms. This is demonstrated in the analysis with only $25 \%$ of disclosures among the RAP sample being of high quality (type 4 or 5) and $11 \%$ for the non-RAP sample. In practice, this means that for many of the components mentioned, firms made either no reference or very limited statements without specifying details. For example, Origin's sustainability report states: 'Through the Origin Foundation we support programs which enable equality of educational opportunity for young people - particularly those from rural and regional locations, and of Aboriginal and Torres Strait Islander heritage, as well as programs which promote and encourage diversity in Science, Technology, Engineering and Maths (STEM)'. Included in a general section outlining community engagement, no further information is provided regarding the Indigenous education support. Similarly, many global firms included sections collectively 
referring to their engagement with Indigenous people across their different countries of operation, with only brief mention of activities in Australia. For example the Anglo American sustainability report includes: 'Examples of these regional initiatives include First Nation Impact and Benefit Agreements (Canada), promotion of Aboriginal procurement (Australia) and black economic empowerment (BEE) (South Africa)'.

Examining disclosure quality between reconciliation components also reveals differences in the detail included for various activities. Table 5 indicates that across the five components analysed, Employment activities were reported in greatest detail for both samples, while Cultural Learning activities were the least detailed. For example, the following passage from Evolution Mining's website, gives very little information as to the format or extent of cultural awareness training being conducted: 'We take our responsibility to protect and manage Cultural Heritage extremely seriously and we are working with our indigenous partners to develop and deliver Cultural Awareness training at each operation to ensure we remain informed and respectful'. Many firms had similar acknowledgements, often linking cultural awareness with cultural heritage and land rights, which are necessary activities for project approval in Australia. Employment opportunities in contrast, represent a highly promoted benefit of resource extraction operations and is often a closely tied with firms' stated social licence to operate. The extent of current employment outcomes and targets for future roles were commonly outlined in detail, often in conjunction with employment support or training programs.

Table 5. Disclosure Quality of Different Components

\begin{tabular}{|l|c|c|c|c|c|}
\hline \multirow{2}{*}{$\begin{array}{l}\text { Reconciliation } \\
\text { Component }\end{array}$} & \multicolumn{2}{|c|}{ RAP Sample } & \multicolumn{2}{c|}{ Non-RAP Sample } & \multirow{2}{*}{ Average } \\
\cline { 2 - 5 } & Reports & Website & Report & Website & \\
\hline Partnerships & 2.2 & 2.8 & 1.4 & 2 & 2.1 \\
\hline Cultural Learning & 0.8 & 1.5 & 0.8 & 0.5 & 0.9 \\
\hline Employment & 3 & 2.4 & 2 & 1.6 & 2.3 \\
\hline Business & 2.6 & 1.5 & 1 & 0.7 & 1.5 \\
\hline Education & 2.5 & 2.6 & 1.4 & 1.6 & 2 \\
\hline
\end{tabular}

\section{Discussion}

This paper presents exploratory insights into the growing corporate engagement in reconciliation, by examining how RAPs align with other CSR reporting practices and how activities are integrated with broader sustainability reporting. This longitudinal sample reveals an overall increase in the number of resources sector firms engaging in the RAP initiative, as well as an evolution in the style and content of reporting. Comparisons between early iterations and current documents, suggests that as companies mature in the program, their Indigenous engagement activities become more complex and allocated greater resources. A distinction from other CSR disclosures is the inclusion of internally orientated activities and strategic emphasis on companies' contribution to the greater reconciliation movement (Lertzman \& Vredenburg, 2005; Langton, 2015). In considering stakeholder theory, the content included in RAPs shows that these activities are not approached in isolation, but rather combined with existing Indigenous engagement practices, particularly in relation to land access and relationships with TO groups (Daly et al., 2013). Finally, while RAPs maintain a common framework, they permit considerably flexibility in disclosure detail and progress reporting, akin to other forms of voluntary reporting initiatives (Raufflet et al., 2014; Michelon et al., 2015). 
The analysis of reconciliation activities disclosed in other reporting platforms provides a number of insights. The first contribution identified that firms with RAPs appear to disclose more detailed information of reconciliation type activities on average than those without. This provides some foundational insight into the influence of the RAP program in increasing stakeholder salience, particularly in an industry where Indigenous engagement is an operational necessity (O'Faircheallaigh, 2013; Parsons, 2008). While the quality of disclosure varied, this indicates public acknowledgement of firms' Indigenous stakeholders and their relevance in terms of CSR practices (Michelon et al., 2015). This comparison indicates firms within the RAP program may place greater emphasis on communicating stakeholder contributions beyond commonly perceived obligations (Campopiano \& De Massis, 2015). It may also link to the emerging role of RA, as a partnered NGO that can be included in disclosures to support and legitimize a company's activities (Nijhof et al., 2008; Lloyd, 2018). Despite this trend, the analysis also identified frequent references to reconciliation type activities from firms without RAPs, indicating alignment with RA is not essential to involvement in reconciliation activities, particularly among resources sector companies with relatively advanced disclosure practices (Parsons et al., 2014; Bice, 2014).

A second outcome of this analysis reveals that Indigenous employment was the component presented in greatest detail across both groups and disclosure channels. This focus is noteworthy, as while stakeholder employment is common practice within the resources sector, communicating these activities is of particular importance to companies, to some extent reflecting underlying CSR objectives (Bice 2014, Fordham et al., 2018). It also supports the notion that the RAP program aligns with the concept of practical rather than symbolic forms of reconciliation (Lloyd, 2018). Employment opportunities are benefits often highlighted by firms to maintain their social license and within the Australian context, these are commonly included in ILUAs (Parsons et al., 2014; O'Faircheallaigh, 2015). To contrast, internal activities such as cultural awareness activities, received less focus despite being an important component of the RAP program. This suggests that while RAPs encourage firms to adopt formalised approaches to reconciliation, disclosure might still influenced by strategic CSR objectives and may not fundamentally alter a firms' relationship with Indigenous stakeholders (Fuisz-Kehrbach, 2015; Raufflet et al., 2014).

Finally, the lack of more detailed disclosures (types 4 and 5) in the sample represents a relative absence of technical detail, which could be considered indicative of deficiencies in sustainability reporting generally (Beck et al., 2010; Milne \& Gray, 2013). This variance in disclosure quality is indicative of the strategic approach to sustainability reporting, taking into account the potential audiences and information control (Boiral \& Henri 2017). It also contrasts with the RAP initiative, in which reports are endorsed by an external NGO and follows a set structure (Boiral \& Henri, 2017). When considered from a social license to operate perspective, externally established reporting frameworks may narrow firms' rhetorical scope to manage stakeholder definitions and commitments (Coronado \& Fallon, 2010). The level of detail is likely to be limited by reporting constraints and broader company scopes, however similar patterns were identified in website disclosures which are arguably more flexible and regionally specific (Bice, 2014). The absence of information relating to these issues could be interpreted as an indication of their perceived materiality (Unerman \& Zappettini, 2014; Russo-Spena et al., 2015). Although the topic of Indigenous engagement is clearly important in the resources sector, there remains no regulatory requirement or institutional standards for disclosing this type of non-financial information (Eccles et al., 2012; O'Faircheallaigh, 2015). 


\section{Conclusion}

This study has provided an empirical foundation through which to identify corporate approaches to reconciliation by examining disclosure behaviours across five dimensions considered central to the reconciliation movement. Ultimately it is difficult to determine a company's commitment to reconciliation based solely on their disclosures, however it does indicate integration into broader CSR strategy, which may at least symbolically advance reconciliation. By making their reconciliation activities public and extending the audience beyond the RAP, companies are in effect acknowledging Indigenous stakeholders and commitments to engagement (Ranängen \& Zobel, 2014; Fuisz-Kehrbach, 2015). Greater formality around corporate efforts in this space is particularly relevant in the resources sector which face direct pressure to address recognition justice issues relating to their operations (O'Faircheallaigh, 2015; Mayes et al., 2014). This research does suggest some influence of the RAP program on corporate disclosure quality, which may help to increase transparency around resources sector engagement activities with Indigenous stakeholders (Langton, 2015).

An outcome of this research is to consider the growing corporate interest in reconciliation within the broader understanding of CSR. It is important to recognise companies have agendas which influence their participation in reconciliation activities and that RAPs themselves are strategic tools with sufficient flexibility to shape disclosures to support company objectives (Haalboom, 2012). Sustainability disclosures, including RAPs, ultimately only tell us what companies say they do, we have limited understanding of their actual performance (Utting, 2005; Milne \& Gray, 2013). Frameworks and NGO supported initiatives do however contribute to more consistent and better quality reporting, which in turn increases accountability and improves exposure which could lead to increased contributions to the reconciliation movement (Conley \& Williams, 2005). Through greater experience with the RAP initiative and greater maturation of the program overall, greater transparency of activity details and outcomes may be expected.

As this research explores an emergent phenomenon, a number of limitations should be noted. The analysis focuses on a small sample of companies due to the low number of companies participating in the RAP program and the need to compare within industry context. This ultimately limits the generalisability of our analysis, however that is not the objective in this instance. Similarly, as the RAP initiative is relatively new we were unable to apply the full CONI methodology given insufficient temporal data (Beck et al., 2010). Comparative analyses based on disclosures are susceptible to the wide variance in reporting styles, which are particularly apparent in the CSR context where firm size, location and ownership structure impact reporting capacity (Bice, 2014; Sethi et al., 2016). More broadly, relying on disclosures as a way to understand RAPs integration into CSR strategy, only provides one, potentially skewed, perspective through which to interpret the multi-faceted CSR practices of firms (Milne \& Gray, 2013).

\section{Agenda for Future Research}

If approached sincerely, formalised approach to practical reconciliation may represent an ethical approach to engage resources sector firms with Indigenous stakeholders, applicable in similar contexts around the world (Lertzman \& Vredenburg, 2005; Craik et al. 2018; Lloyd, 2018). As this area develops, future research may be able to expand the analysis to include more companies, different industries and alternative forms of disclosures (Nijhof et al., 2008). It is also important to recognise that reconciliation activities concern CSR issues within a specific operational context and there may be limited space available within broader reports, 
however this presents opportunities to explore how social license to operate is operationalised at local site level and extra local levels (Bice 2014). Furthermore, adding a temporal aspect to future analysis will allow for a better understanding of the impact of the RAP program over time, as firms develop their internal processes and advance through the commitment tiers established by RA.

While accessing true measures of firm CSR performance is a perennial problem, with advancements in third-party auditing, mandatory standards and analytical techniques, we have come some way to better understanding the effectiveness of CSR activities (Beck et al., 2018). By comparison, evaluation within the RAP domain is nascent, relying on a limited aggregate survey and corporate self-reporting which is often sporadic and incomplete (Lloyd, 2018). It remains to be seen how far the RAP program will grow, however RA has the potential to become an influential body that sets the reporting standards expected of Australian companies or others operating in the country (Ranängen \& Zobel, 2014). There is immediate value in increasing transparency by tracking and linking corporate RAP targets with performance outcomes from publically available information, which can provide standards of effectiveness and potential learning opportunities. Empirical research should also consider how employee attitudes change through this program, as well as capturing perceptions of reconciliation performance from Indigenous community members to offer a more meaningful gauge of RAP impact. Future studies should ultimately aim to examine the original tenet of the RAP program 'turning good intentions into action', in clarifying the link between these corporate actions and tangible outcomes for Indigenous Australians.

\section{References}

Aguinis, H. (2011), "Organisational responsibility: doing good and doing well", in Zedeck, S. (Ed.), APA Handbook of Industrial and Organizational Psychology, Vol. 3, American Psychological Association, Washington, DC, pp. 855-879.

Aguinis, H., \& Glavas, A (2012). What We Know and Don't Know About Corporate Social Responsibility: A Review and Research Agenda. Journal of Management, 38(4), 932-968.

BCA (2016) Indigenous Engagement Survey Summary Report. Accessed 7/11/2017.

Retrieved from: http://www.bca.com.au/publications/2016-indigenous-engagement-survey

Beck, C., Campbell, D., \& Shrives, P. J. (2010). Content analysis in environmental reporting research: Enrichment and rehearsal of the method in a British-German context. British Accounting Review, 42(3), 207-222.

Beck, C., Frost, G., \& Jones, S. (2018). CSR disclosure and financial performance revisited: A cross-country analysis. Australian Journal of Management, 43(4), 517-537.

Bice, S. (2014). What gives you a social licence? An exploration of the social licence to operate in the Australian mining industry. Resources, 3(1), 62-80.

Bice, S. (2017). Corporate social responsibility as institution: A social mechanisms framework. Journal of Business Ethics, 143(1), 17-34.

Boiral, O. (2013). Sustainability reports as simulacra? A counter-account of A and A+ GRI reports. Accounting, Auditing \& Accountability Journal. Vol. 26 No. 7, 2013 pp. 1036-1071 
Boiral, O., \& Henri, J. F. (2017). Is sustainability performance comparable? A study of GRI reports of mining organizations. Business \& Society, 56(2), 283-317.

Campopiano, G., \& De Massis, A. (2015). Corporate social responsibility reporting: A content analysis in family and non-family firms. Journal of Business Ethics, 129(3), 511-534.

Chen, S., \& Bouvain, P. (2009). Is corporate responsibility converging? a comparison of corporate responsibility reporting in the USA, UK, Australia, and Germany. Journal of Business Ethics, 87(SUPPL. 1), 299-317.

Conley, J. M., \& Williams, C. A. (2005). Engage, Embed, and Embellish: Theory Versus Practice in the Corporate Social Responsibility Movement. Journal of Corporation Law, 31(1), $1-38$.

Coronado, G., \& Fallon, W. (2011). Using hypertext ethnography to understand corporatestakeholder relations in CSR. Social Responsibility Journal, 7(1), 87-103.

Craik, N., Gardner, H., \& McCarthy, D. (2017). Indigenous-corporate private governance and legitimacy: Lessons learned from impact and benefit agreements. Resources Policy, 52, 379388.

Crawley, A., \& Sinclair, A. (2003). Indigenous Human Resource Practices in Australian Mining Companies: Towards an Ethical Model. Journal of Business Ethics, 45(4), 361-373.

Daly, A., Gebremedhin, T., \& Sayem, M. (2013). A case study of affirmative action Australianstyle for Indigenous people. Australian Journal of Labour Economics, 16(2), 277.

Eccles, R. G., Krzus, M. P., Rogers, J., \& Serafeim, G. (2012). The Need for Sector-Specific Materiality and Sustainability Reporting Standards. Applied Corporate Finance, 24(2), 6571.

Fifka, M. S. (2013). Corporate responsibility reporting and its determinants in comparative perspective-a review of the empirical literature and a meta-analysis. Business strategy and the environment, 22(1), 1-35.

Fonseca, A. (2010). How credible are mining corporations' sustainability reports? A critical analysis of external assurance under the requirements of the international council on mining and metals. Corporate Social Responsibility and Environmental Management, 17(6), 355-370.

Fordham, A. E., Robinson, G. M., \& Blackwell, B. D. (2017). Corporate social responsibility in resource companies-Opportunities for developing positive benefits and lasting legacies. Resources Policy, 52, 366-376.

Fordham, A. E., Robinson, G. M., Cleary, J., Blackwell, B. D., \& Van Leeuwen, J. (2018). Use of a multiple capital framework to identify improvements in the CSR strategies of Australian resource companies. Journal of Cleaner Production, 200, 704-730.

Fuisz-Kehrbach, S. K. (2015). A three-dimensional framework to explore corporate sustainability activities in the mining industry: Current status and challenges ahead. Resources Policy, 46, 101-115. 
Hahn, R., \& Kühnen, M. (2013). Determinants of sustainability reporting: a review of results, trends, theory, and opportunities in an expanding field of research. Journal of Cleaner Production, 59, 5-21.

Haalboom, B. (2012). The intersection of corporate social responsibility guidelines and indigenous rights: Examining neoliberal governance of a proposed mining project in Suriname. Geoforum, 43(5), 969-979.

Heard, I., Love, P. E., Sing, M. C., \& Goerke, V. (2017). Learning to build relationships for a better Australia: Indigenous reconciliation in action in the construction and resource sectors. Construction Innovation, 17(1), 4-24.

Hess, D. (2008). The Three Pillars of Corporate Social Reporting As New Governance Regulation: Disclosure, Dialogue, and Development. Business Ethics Quarterly 18, 447-482.

Hetze, K. (2016). Effects on the ( CSR ) Reputation : CSR Reporting Discussed in the Light of Signalling and Stakeholder Perception Theories. Corporate Reputation Review, 19(3), 281296.

Hilson, G. (2012). Corporate Social Responsibility in the extractive industries: Experiences from developing countries. Resources Policy, 37(2), 131-137.

Humphreys, A. (2014). How is Sustainability Structured? The Discursive Life of Environmentalism. Journal of Macromarketing, 34(3), 265-281.

Johnson, Harold L. (1971), Business in Contemporary Society: Framework and Issues. Wadsworth Publishing. Belmont, CA.

Jenkins, H. (2004). Corporate social responsibility and the mining industry: Conflicts and constructs. Corporate Social Responsibility and Environmental Management, 11(1), 23-34.

Jenkins, H., \& Yakovleva, N. (2006). Corporate social responsibility in the mining industry: Exploring trends in social and environmental disclosure. Journal of Cleaner Production, 14(34), 271-284.

Langton, M., \& Mazel, O. (2008). Poverty in the midst of plenty: Aboriginal people, the 'resource curse'and Australia's mining boom. Journal of energy \& natural resources law, 26(1), 31-65.

Langton, M. (2015). From conflict to cooperation: Transformations and challenges in the engagement between the Australian minerals industry and Australian indigenous peoples. Minerals Council of Australia.

Lee, K. H. (2017). Does size matter? Evaluating corporate environmental disclosure in the Australian mining and metal industry: A combined approach of quantity and quality measurement. Business Strategy and the Environment, 26(2), 209-223.

Lloyd, C. (2018). Reconciliation Action Plans: Origins, innovations and trends. Journal of Australian Indigenous Issues, 21(4), 10-45.

Lozano, R., \& Huisingh, D. (2011). Inter-linking issues and dimensions in sustainability reporting. Journal of Cleaner Production, 19(2), 99-107. 
Mayes, R., McDonald, P., \& Pini, B. (2014). 'Our' community: corporate social responsibility, neoliberalisation, and mining industry community engagement in rural Australia. Environment and Planning A, 46(2), 398-413.

Michelon, G., Pilonato, S., \& Ricceri, F. (2015). CSR reporting practices and the quality of disclosure: An empirical analysis. Critical Perspectives on Accounting, 33, 59-78.

Milne, M. J., \& Gray, R. (2013). W(h)ither Ecology? The Triple Bottom Line, the Global Reporting Initiative, and Corporate Sustainability Reporting. Journal of Business Ethics, $118(1), 13-29$.

Nijhof, A., de Bruijn, T., \& Honders, H. (2008). Partnerships for corporate social responsibility. Management Decision, 46(1), 152-167.

O'Faircheallaigh, C. (2013). Extractive industries and Indigenous peoples: A changing dynamic ? Journal of Rural Studies, 30, 20-30.

O'Faircheallaigh, C. (2015). Social Equity and Large Mining Projects: Voluntary Industry Initiatives, Public Regulation and Community Development Agreements. Journal of Business Ethics, 132(1), 91-103.

Parsons, R. (2008). We are all stakeholders now: The influence of western discourses of "community engagement" in an Australian Aboriginal community. Critical Perspectives on International Business, 4(2/3), 99-126.

Parsons, R., Lacey, J., \& Moffat, K. (2014). Maintaining legitimacy of a contested practice: How the minerals industry understands its 'social licence to operate'. Resources Policy, 41, 8390

Pérez, A. (2015). Corporate reputation and CSR reporting to stakeholders. Corporate Communications: An International Journal, 20(1), 11-29.

Polity (2016) Australian Reconciliation Barometer 2016. Accessed 2/11/2017. Retrieved from www.reconciliation.org.au/raphub/wp-content/uploads/2017/.../WRB-report-2016.pdf

Prno, J., \& Scott Slocombe, D. (2012). Exploring the origins of "social license to operate" in the mining sector: Perspectives from governance and sustainability theories. Resources Policy, $37(3), 346-357$.

Ranängen, H., \& Zobel, T. (2014). Revisiting the "how" of corporate social responsibility in extractive industries and forestry. Journal of Cleaner Production, 84, 299-312.

Raufflet, E., Barin Cruz, L., \& Bres, L. (2014). An assessment of corporate social responsibility practices in the mining and oil and gas industries. Journal of Cleaner Production, 84, 256-270.

Reconciliation Australia (2016) The State of Reconciliation in Australia Report. Accessed 2/11/2017. Retrieved from: https://www.reconciliation.org.au/the-state-of-reconciliation-inaustralia-report/

Russo-Spena, T., Tregua, M., \& De Chiara, A. (2018). Trends and drivers in CSR disclosure: A focus on reporting practices in the automotive industry. Journal of Business Ethics, 151(2), 563-578. 
Sethi, S. P., Martell, T. F., \& Demir, M. (2016). Building Corporate Reputation Through Corporate Social Responsibility (CSR) Reports : The Case of Extractive Industries. Corporate Reputation Review, 19(3), 219-243.

Trebeck, K. (2008). Exploring the responsiveness of companies: corporate social responsibility to stakeholders. Social Responsibility Journal, 4(3), 349-365.

Unerman, J., \& Zappettini, F. (2014). Incorporating materiality considerations into analyses of absence from sustainability reporting. Social and Environmental Accountability Journal, 34(3), 172-186.

Utting, P. (2005) Corporate responsibility and the movement of business. Development in Practice 15 (3-4), 375-388.

Van der Laan, S. (2009). The role of theory in explaining motivation for corporate social disclosures: Voluntary disclosures vs 'solicited' disclosures. Australasian Accounting, Business and Finance Journal, 3(4), 2. 


\section{Appendix}

Table A1 Disclosure Quality of Sustainability Reports (Reconciliation Action Plans Sample)

\begin{tabular}{|l|l|l|l|l|l|l|}
\hline Company & Partnership & $\begin{array}{l}\text { Cultural } \\
\text { Learning }\end{array}$ & Employment & Business & Education & Average \\
\hline Anglo American & 0 & 0 & 0 & 1 & 0 & 0.2 \\
\hline Arrow & - & - & - & - & - & - \\
\hline BHP Billiton & 1 & 0 & 5 & 5 & 4 & 3 \\
\hline BP Australia & 0 & 0 & 3 & 3 & 0 & 1.2 \\
\hline Chevron & 5 & 0 & 0 & 0 & 0 & 1 \\
\hline Glencore & 1 & 0 & 4 & 0 & 2 & 1.4 \\
\hline INPEX & 3 & 2 & 4 & 4 & 3 & 3.2 \\
\hline Newmont & 2 & 2 & 3 & 3 & 5 & 3 \\
\hline Origin & 2 & 0 & 5 & 4 & 4 & 3 \\
\hline Rio Tinto & 2 & 2 & 4 & 2 & 2 & 2.4 \\
\hline Shell & 2 & 0 & 0 & 2 & 0 & 0.8 \\
\hline South 32 & 2 & 0 & 1 & 1 & 2 & 1.2 \\
\hline Whitehaven Coal & 4 & 2 & 5 & 4 & 5 & 4 \\
\hline Woodside & 4 & 3 & 5 & 5 & 5 & 4.4 \\
\hline Average & 2.2 & 0.8 & 3 & 2.6 & 2.5 & 2.2 \\
\hline
\end{tabular}

Table A2 Disclosure Quality of Sustainability Reports (Non- Reconciliation Action Plan Sample)

\begin{tabular}{|l|l|l|l|l|l|l|}
\hline Company & Partnership & $\begin{array}{l}\text { Cultural } \\
\text { Learning }\end{array}$ & $\begin{array}{l}\text { Employmen } \\
\mathrm{t}\end{array}$ & Business & Education & Average \\
\hline Alcoa & 1 & 0 & 0 & 0 & 0 & 0.2 \\
\hline Anglogold Ashanti & 0 & 0 & 0 & 0 & 2 & 0.4 \\
\hline Beach Energy & 0 & 1 & 1 & 0 & 1 & 0.6 \\
\hline ConocoPhillips & 2 & 2 & 3 & 1 & 2 & 2 \\
\hline Evolution & 2 & 1 & 3 & 1 & 2 & 1.8 \\
\hline FMG & 2 & 4 & 5 & 4 & 4 & 3.8 \\
\hline Iluka & 2 & 1 & 5 & 1 & 1 & 2 \\
\hline New Hope & 0 & 0 & 0 & 1 & 1 & 0.4 \\
\hline Newcrest & 2 & 1 & 4 & 2 & 2 & 2.2 \\
\hline Oz Minerals & 2 & 1 & 3 & 1 & 0 & 1.4 \\
\hline Peabody & 1 & 0 & 1 & 1 & 1 & 0.8 \\
\hline Santos & 1 & 0 & 1 & 0 & 0 & 0.4 \\
\hline Senex & 1 & 1 & 2 & 2 & 0 & 1.5 \\
\hline Yancoal & 4 & 0 & 1 & 1 & 4 & 1.8 \\
\hline Average & 1.4 & 0.8 & 2 & 1 & 1.4 & 1.4 \\
\hline
\end{tabular}


Table A3 Disclosure Quality of Website Data (Reconciliation Action Plan Sample)

\begin{tabular}{|l|l|l|l|l|l|l|}
\hline Company & Partnership & $\begin{array}{l}\text { Cultural } \\
\text { Learning }\end{array}$ & Employment & Business & Education & Average \\
\hline Anglo American & 2 & 1 & 0 & 0 & 2 & 1 \\
\hline Arrow & 2 & 1 & 2 & 1 & 4 & 2 \\
\hline BHP & 4 & 2 & 3 & 3 & 3 & 3 \\
\hline BP Australia & 2 & 1 & 1 & 2 & 2 & 1.6 \\
\hline Chevron & 5 & 2 & 1 & 2 & 2 & 2.4 \\
\hline Glencore & 2 & 0 & 4 & 1 & 2 & 1.8 \\
\hline INPEX & 3 & 1 & 3 & 3 & 4 & 2.8 \\
\hline Newmont & 2 & 2 & 2 & 1 & 2 & 1.8 \\
\hline Origin & 2 & 2 & 1 & 2 & 3 & 2 \\
\hline Rio Tinto & 4 & 0 & 4 & 2 & 2 & 2.4 \\
\hline Shell & 1 & 1 & 4 & 1 & 1 & 1.6 \\
\hline South 32 & 4 & 1 & 1 & 0 & 4 & 2 \\
\hline Whitehaven Coal & 2 & 4 & 4 & 0 & 4 & 2.8 \\
\hline Woodside & 4 & 3 & 3 & 3 & 2 & 3 \\
\hline Average & 2.8 & 1.5 & 2.4 & 1.5 & 2.6 & 2.2 \\
\hline
\end{tabular}

Table A4 Disclosure Quality of Website Data (Non- Reconciliation Action Plan Sample)

\begin{tabular}{|l|l|l|l|l|l|l|}
\hline Company & Partnership & $\begin{array}{l}\text { Cultural } \\
\text { Learning }\end{array}$ & $\begin{array}{l}\text { Employme } \\
\text { nt }\end{array}$ & Business & Education & Average \\
\hline Alcoa & 2 & 0 & 0 & 0 & 0 & 0.4 \\
\hline Anglogold Ashanti & 0 & 0 & 0 & 0 & 0 & 0 \\
\hline Beach Energy & 0 & 0 & 0 & 0 & 2 & 0.4 \\
\hline ConocoPhillips & 4 & 2 & 2 & 2 & 2 & 2.4 \\
\hline Evolution & 2 & 1 & 3 & 2 & 1 & 1.8 \\
\hline FMG & 4 & 0 & 3 & 4 & 4 & 3 \\
\hline Iluka & 2 & 1 & 3 & 1 & 1 & 1.6 \\
\hline New Hope & 2 & 0 & 0 & 0 & 0 & 0.2 \\
\hline Newcrest & 1 & 0 & 4 & 0 & 1 & 1.2 \\
\hline Oz Minerals & 2 & 2 & 3 & 0 & 4 & 2.2 \\
\hline Peabody & 1 & 0 & 0 & 0 & 0 & 0.2 \\
\hline Santos & 4 & 0 & 3 & 1 & 4 & 2.4 \\
\hline Senex & 2 & 1 & 0 & 0 & 0 & 0.6 \\
\hline Yancoal & 2 & 0 & 1 & 0 & 3 & 1.2 \\
\hline Average & 2 & 0.5 & 1.6 & 0.7 & 1.6 & 1.3 \\
\hline
\end{tabular}

